\title{
The population biology and life history traits of Eurasian ruffe [Gymnocephalus cernuus (L.), Pisces: Percidae] introduced into eutrophic and oligotrophic lakes in Northern Italy
}

\author{
Pietro VOLTA, ${ }^{1 *}$ Erik JEPPESEN,,${ }^{2}$ Barbara CAMPI, ${ }^{1}$ Paolo SALA,${ }^{1}$ Matthias EMMRICH,,${ }^{3}$ Ian J. WINFIELD ${ }^{4}$ \\ ${ }^{1}$ CNR Institute of Ecosystem Study, Verbania Pallanza, Italy; ${ }^{2}$ Department of Bioscience and The Arctic Centre, Aarhus University, \\ Denmark; ${ }^{3}$ Leibniz-Institute of Freshwater Ecology and Inland Fisheries, Berlin, Germany; ${ }^{4}$ Centre for Ecology and Hydrology, \\ Lancaster Environment Centre, Library Avenue, Bailrigg, UK \\ *Corresponding author: p.volta@ise.cnr.it
}

\begin{abstract}
We describe the population biology and life-history traits of two Eurasian ruffe [Gymnocephalus cernuus (L.), Pisces: Percidae] populations which have recently colonised two small lakes in the lake Maggiore catchment of Northern Italy, the eutrophic lake (l.) Ghirla (ruffe first recorded in the early 1990s) and the oligotrophic l. Mergozzo (ruffe first recorded during the present sampling in 2010). Survey gill net catches revealed that ruffe has become one of the most abundant fish species in both lakes. Relative weight and weight-length relationships indicated better growth of ruffe in l. Mergozzo. Thus, gonad weight, adjusted for body size, was higher in l. Mergozzo, indicating a stronger individual reproductive potential in the more recently colonised lake. The stomach contents of ruffe were dominated by chironomid larvae and other benthic organisms, while pelagic microcrustaceans only occurred in small amounts. The ratio of benthic vs pelagic prey in the diet increased with ruffe size. Ruffe intraspecific food niche overlap (based on prey numbers) between age classes was slightly higher in oligotrophic l. Mergozzo than in eutrophic l. Ghirla and decreased with age in both lakes.
\end{abstract}

Key words: invasive alien species, introductions, biological pressures, percids, diets.

Received: May 2012. Accepted: January 2013.

\section{INTRODUCTION}

The Eurasian ruffe [Gymnocephalus cernuus (L.)] (hereafter ruffe) is a European member of the Percidae family and has recently become a successful invader in parts of Europe and elsewhere (Gunderson et al., 1998). Being a temperate zone mesothermic fish species (Hokanson, 1977), the native distributional range of ruffe includes the Caspian, Aral, Black, Baltic and North sea basins as far as Siberia (Kottelat and Freyhof, 2007). In the latter part of the previous century, ruffe was accidentally introduced into parts of France (Matthey, 1966), the UK (Maitland and East, 1989; Winfield et al., 1996) and the Great Lakes region of North America (Pratt et al., 1992), where its arrival has caused considerable concern.

This eurytopic percid is a remarkably adaptable species and thus an efficient invader. It is able to adapt to many types of water bodies and tolerates marked variations in salinity (Lind, 1977) and productivity (Persson et al., 1991; Mehner et al., 2005) as well as different habitats (Kålås, 1995; Ogle, 1998) and depths (Sandlund et al., 1985). Ruffe is typically invertivorous (Balon et al., 1977), feeding preferentially on benthic organisms, but also occasionally consuming zooplankton (Hölker and Thiel, 1998; Popova et al., 1998). Fish eggs (Adams and
Tippett, 1991; Kangur and Kangur, 1996; Rösch and Schmid, 1996; Winfield et al., 2004b) and small fishes (Hölker and Thiel, 1998; and references therein) have also been recorded in the diet of lacustrine populations, making ruffe a potentially significant predator on fish species such as coregonids (Rösch and Schmid, 1996; Winfield et al., 1996). Fecundity is high and reproduction can start from an age as young as one or two years, with males maturing earlier than females (Berg, 1965; Popova et al., 1998; Devine et al., 2000; Lorenzoni et al., 2009). The species is of negligible economic value and is generally unattractive for recreational fishing, although its use as live bait by anglers fishing for pike [Esox lucius (L.)] has frequently been linked to its recent dispersal (Winfield and Durie, 2004). Ruffe invasion raises concern about its impacts on local native fish species. A potential negative impact of ruffe on perch [Perca fluviatilis (L.)] has been recorded in laboratory experiments (Bergman, 1987; Savino and Kolar, 1996) and some but not all field studies (Bergman, 1991; Bergman and Greenberg, 1994; Winfield et al., 2004a). Management and control of invasive ruffe populations have been attempted by stocking predators (Mayo et al., 1998), using piscicides (Dawson et al., 1998), or by selective removal (Popova et al., 1998; Czypinski and Ogle, 2011). The results of such measures have, 
however, been ambiguous (Pihu and Maemets, 1982; Dawson et al., 1998; Mayo et al., 1998; Popova et al., 1998; Czypinski and Ogle, 2011).

Although the biology and ecology of ruffe have been extensively described for the temperate-cold regions of its native parts of Europe and the parts of North America where it has been introduced (Gunderson et al., 1998, and references therein), knowledge of its population biology and life history in more southerly Mediterranean areas is scarce and limited to the basin of the Tevere river near Rome, Italy (Carosi et al., 1998; Lorenzoni et al., 2007). In Italy, ruffe was recorded for the first time during the 1980s in the Isonzo river (Chiara, 1986). Subsequently, it has also been found at more westerly Italian locations at the lower stretch of the Adda river (Chiozzi, 1995) and the Po river (De Curtis and Rossi, 1999), and at more southerly locations in lakes Piediluco and Corbara (Central Italy) of the river Tevere system (Carosi et al., 1998; Lorenzoni et al., 2007).

In this study we describe the population biology and life history traits of ruffe introduced to two small lakes, eutrophic lake (1.) Ghirla and the oligotrophic 1. Mergozzo, located in the lake Maggiore catchment in Northern Italy. The two lakes were colonised by ruffe during different time periods, being first recorded in 1 . Ghirla in the early 1990s (GRAIA, 2001) and in 1. Mergozzo during the present study in 2010 and not in previous fish surveys undertaken in the mid-1990s (Giussani, 1994) and 2000 (GRAIA, 2000). Thus, these lakes offer the possibility of characterising life history traits of ruffe under different environmental conditions and at different stages of the invasion process. Moreover, as both lakes are located in the Po river basin, which is the largest river basin in Italy thereby offering a major potential for further dispersal, a detailed characterisation of the two ruffe populations may provide important insight into invasion processes in Southern Europe.

\section{METHODS}

\section{Study sites}

L. Mergozzo is a deep (maximum depth: $73 \mathrm{~m}$ ) but relatively small (surface area: $1.83 \mathrm{~km}^{2}$ ) lake located in Piedmont region $\left(45^{\circ} 57^{\prime} \mathrm{N}, 8^{\circ} 27^{\prime} \mathrm{E}\right)$, and 1 . Ghirla is a shallower (maximum depth: $14 \mathrm{~m}$ ) and smaller (surface area: $0.24 \mathrm{~km}^{2}$ ) regulated lake located in Lombardy region $\left(45^{\circ} 54^{\prime} \mathrm{N}, 8^{\circ} 49^{\prime} \mathrm{E}\right)$. L. Mergozzo is located at $193 \mathrm{~m}$ asl and is oligotrophic (TP ca. $4 \mu \mathrm{g} \mathrm{L}^{-1}$ ), while 1. Ghirla is located at $442 \mathrm{~m}$ asl and is eutrophic (TP ca. $40 \mu \mathrm{g} \mathrm{L}^{-1}$ ). The littoral substrate in both lakes consists mostly of sand and cobble, with a minor percentage of boulder and gravel. Submerged macrophytes are extremely scarce, while a reed bed (Phragmites australis) is found along the shoreline in both lakes (Volta, unpublished data).

\section{Fish sampling and catch processing}

Benthic survey gill nets were used for fish sampling (Appelberg et al., 1995). Each benthic net was $30 \mathrm{~m}$ long and $1.5 \mathrm{~m}$ high and composed of twelve panels with mesh sizes ranging from $5.5 \mathrm{~mm}$ to $55 \mathrm{~mm}$. In 1. Ghirla, fish were sampled between 5 and 8 October 2010, 16 gill nets were distributed randomly within three different depth strata ( 0 to $2.9 \mathrm{~m}, 3.0$ to $5.9 \mathrm{~m}$, and deeper than $6.0 \mathrm{~m}$ ). In the deeper 1. Mergozzo, fish were sampled between 12 and 14 October 2010, 32 nets were set in seven depth strata (0 to $2.9 \mathrm{~m}, 3.0$ to $5.9 \mathrm{~m}, 6.0$ to $11.9 \mathrm{~m}, 12.0$ to $19.9 \mathrm{~m}, 20.0$ $\mathrm{m}$ to $34.9 \mathrm{~m}, 35.0$ to $49.9 \mathrm{~m}$, and deeper than $50.0 \mathrm{~m}$ ). The number of nets in each lake was determined in order to sample with approximately the same effort in each depth stratum. Nets were set at dusk between 6 and 7 p.m. and lifted the following morning between 7 and 8 a.m.

Captured fish were measured (total length to nearest $0.1 \mathrm{~cm}, \mathrm{~L}_{\mathrm{T}}$ ), weighed (fresh total weight to nearest 0.01 $\mathrm{g}, \mathrm{W}_{\mathrm{T}}$ ) and sexed (female, male, indeterminable) by examination of gonads. Gonads were excised and weighed to nearest $0.01 \mathrm{~g}$. Ten scales from each ruffe were taken from behind the pectoral fin and under the lateral line and subsequently used for age determination, with 15 May considered the nominal date of birth. Stomachs of ruffe were removed and stored in 3\% formaldehyde for subsequent diet analyses.

\section{Data analysis}

Catch per unit effort was calculated as fish biomass per unit effort (BPUE, $g$ net $^{-1}$ ) and fish number per unit effort by nets (NPUE, number net ${ }^{-1}$ ) for individual species and for all species pooled.

For ruffe, the relationship between $\mathrm{W}_{\mathrm{T}}$ and $\mathrm{L}_{\mathrm{T}}(\log$ transformed) was calculated for males, females and males, and females pooled using the model:

$$
\log \left(\mathrm{W}_{\mathrm{T}}\right)=\mathrm{b} * \log \left(\mathrm{L}_{\mathrm{T}}\right)+\log (\mathrm{a})
$$

Actual length-at-age of ruffe was used to estimate the parameters of the von Bertalanffy (1938) growth function (VBGF) according to the equation:

$$
\mathrm{L}_{\mathrm{T}}=\mathrm{L}_{\infty}\left(1-\mathrm{e}^{-\mathrm{K}\left(\mathrm{t}-\mathrm{t}_{0}\right)}\right)
$$

where $\mathrm{L}_{\infty}$ is the theoretical asymptotic length $(\mathrm{cm})$ that an average fish may achieve, $\mathrm{K}$ is the constant [year $\left(\mathrm{y}^{-1}\right)$ ] which determines how fast the fish approaches $\mathrm{L}_{\infty}$, and $\mathrm{t}_{0}$ (y) is the hypothetical age at $\mathrm{L}_{\mathrm{T}}=0$.

Relative weight (Wr) was calculated for the two ruffe populations by dividing the observed total weight by the standard weight (Ws) calculated by means of the quadratic $E m P \mathrm{Ws}_{50}$ equation following Ogle and Winfield (2009): 
$\log _{10}\left(\mathrm{Ws}_{50}\right)=-3.3524+1.3969 * \log _{10}\left(\mathrm{~L}_{\mathrm{T}}\right)+0.4054 *\left[\log _{10}\left(\mathrm{~L}_{\mathrm{T}}\right)\right]^{2}$

(eq. 3)

where $\mathrm{Ws}_{50}$ is a length-specific standard weight (based on the $50^{\text {th }}$ percentile of mean weights predicted by a lengthweight regression from 91 ruffe data sets obtained from waters across Europe and the Laurentian Great Lakes). As suggested by Ogle and Winfield (2009), the use of $\mathrm{Ws}_{50}$ is more suitable than $\mathrm{Ws}_{75}$ (standard weight based on $75^{\text {th }}$ percentile) in the case of an unexploited fish population. Relative weight was first compared within different length categories for each population [for the setting of length categories see Ogle and Winfield (2009)] and, if not significantly different, data were pooled together and compared between the two populations. The length categories for ruffe were: 55 to $89 \mathrm{~mm}, 90$ to $119 \mathrm{~mm}, 120$ to 139 $\mathrm{mm}, 140$ to $174 \mathrm{~mm}$ and 175 to $205 \mathrm{~mm}$.

The Phi'-prime index (Pauly and Munro, 1984) was calculated to compare the growth performance of ruffe as:

$$
\Phi^{`}=\log _{10}(\mathrm{~K})+2 * \log _{10}\left(\mathrm{~L}_{\infty}\right)
$$

\section{Diet analysis}

Stomach solid contents were isolated using a filter before drying for 15 minutes on blotting paper. Prey items were identified as accurately as possible to genus or species level under a stereomicroscope. Benthos and zooplankton were identified according to Campaioli et al. (1994) and Margaritora (1983), respectively.

Data were analysed using a two-dimensional representation of the diet as described by Amundsen et al. (1996), with every point representing, for each prey type, the frequency of occurrence $(\mathrm{S} i)$ (i.e. the percentage ratio between the number of stomachs where the prey $i$ was found and the total number of stomachs) and the prey-specific abundance $(\mathrm{P} i)$ (i.e. the percentage that a prey taxon comprises of all prey items only in those stomachs where that prey occurs). Using this method, it is possible to assess the importance of the prey in the diet (dominant or rare) and the type of diet (specialised or generalised), both of which are linked to the between- and within-phenotype contributions to the niche width. In a population with a high betweenphenotype component, different individuals specialise on different resource types, whereas in populations with a high within-phenotype component, most of the individuals utilise many resource types simultaneously.

For each lake, food niche overlap between the different age classes $(0+, 1+, 2+)$ and average values for each lake were calculated using Schoener's index (Schoener, 1970):

$$
\alpha=1-0.5\left(\sum_{i=1}^{n} \mid \text { V.I. } \cdot_{x i}-V_{I_{y i}}\right)
$$

where $\alpha$ is the index value, $\mathrm{n}$ the number of prey categories, V.I. ${ }_{x i}$ the proportion of the prey category $i$ in species $\mathrm{X}$, and V.I $\mathrm{I}_{\mathrm{y} i}$ the proportion of the prey category $i$ in species $\mathrm{Y}$.

V.I. was calculated as follows:

$$
\text { V.I. }=\% \mathrm{~N} * \mathrm{~S} i^{0.5}
$$

where $\% \mathrm{~N}$ is the percentage ratio between the number of prey in the stomachs and the total number of prey, and $\mathrm{S} i$ has been defined above. The $\alpha$ index ranges from 0 (no overlap) to 1 (complete overlap).

\section{Statistics}

Differences between the median sizes (total length) and relative weight Wr of the two populations were tested with Mann Whitney U tests. Differences in Wr within each population were tested by Kruskal Wallis test. Differences in the length-weight ordinary least squares (OLS) regressions and weight of the gonad (adjusted for body size and lake) of ruffe were tested by ANOVAs. Differences of VBGF parameters $\left(\mathrm{L}_{\infty}, \mathrm{t} 0\right.$, and $\left.\mathrm{K}\right)$ among different groups were determined by the analyses of variance of several VBGF models. Models include a general model containing separate VBGF parameter estimates for individuals in each group, and different common models with one, two or three parameters in common between the groups. The best (most parsimonious) model was identified by using the Akaike information criterion (AIC). Uncertanties in VBGF parameters were assessed by bootstrapping. Phi' variability was determined by using boostrapped confidence intervals of VBGF. Differences in the proportion of females were tested by Chi-square tests. Differences were significant with $\mathrm{P}<0.05$.

Statistical analyses were performed in $\mathrm{R}$ software version 2.15.2 (R Development Core Team, 2010) by means of the FSA and NCStats packages (Ogle, 2012) the nlstools package and Sigmaplot software version 11 (Systat Inc., Chicago, IL, USA; Baty and Delignette-Muller, 2012).

\section{RESULTS}

\section{Fish sampling}

Total NPUE was seven times higher in 1. Ghirla than in 1. Mergozzo, and total BPUE was four times higher (Tab. 1). Six and 15 species were sampled in 1 . Ghirla and 1. Mergozzo, respectively. In 1. Ghirla, perch and roach [Rutilus rutilus (L.)] dominated in numbers, followed by rudd [Scardinius erythrophthalmus (L.)] and ruffe. Roach was by far the most abundant species in 1. Mergozzo followed by ruffe, perch and rudd.

\section{Ruffe population characteristics}

In both lakes, ruffe were captured at all depth strata except the deepest one (Fig. 1A). The NPUE of ruffe was less 
than twofold higher in 1. Ghirla than in 1. Mergozzo whilst the BPUE was similar in the two lakes (Tab. 1). The median length of ruffe was higher (Mann-Whitney, $\mathrm{U}=844.50$, $\mathrm{P}=0.041)$ in 1 . Ghirla $(11.6 \mathrm{~cm} \pm 0.31 \mathrm{SE})$ than in 1 . Mergozzo ( $8.7 \mathrm{~cm} \pm 0.31 \mathrm{SE})$ (Fig. 1B). Five age classes (age $0^{+}$ to $4^{+}$) were found in 1 . Mergozzo and three age classes (age $0^{+}$to $2^{+}$) were detected in 1 . Ghirla (Fig. 1C).

\section{Body growth}

Body growth data are shown in Fig. 2. Ruffe lengthweight relationships in 1. Mergozzo were:

$$
\begin{aligned}
& \log (\mathrm{Wt})=2.773 * \log (\mathrm{Lt})-3.784 \\
& \quad\left(\mathrm{males}, \mathrm{n}=39, \mathrm{R}^{2}=0.979, \mathrm{P}<0.001\right) \\
& \log (\mathrm{Wt})=2.962 * \log (\mathrm{Lt})-4.205 \\
& \quad\left(\mathrm{females}, \mathrm{n}=16, \mathrm{R}^{2}=0.985, \mathrm{P}<0.001\right) \\
& \log (\mathrm{Wt})=2.811 * \log (\mathrm{Lt})-3.870 \\
& \quad\left(\text { pooled sexes, } \mathrm{n}=55, \mathrm{R}^{2}=0.983, \mathrm{P}<0.001\right)
\end{aligned}
$$

While the equivalent relationships in 1. Ghirla were:

$$
\begin{aligned}
& \log (\mathrm{Wt})=3.089 * \log (\mathrm{Lt})-4.579 \\
& \quad\left(\text { males, } \mathrm{n}=33, \mathrm{R}^{2}=0.987, \mathrm{P}<0.001\right) \\
& \log (\mathrm{Wt})=3.125 * \log (\mathrm{Lt})-4.662 \\
& \quad\left(\mathrm{females}, \mathrm{n}=15, \mathrm{R}^{2}=0.984, \mathrm{P}<0.001\right) \\
& \log (\mathrm{Wt})=3.097 * \log (\mathrm{Lt})-4.597 \\
& \quad\left(\text { pooled sexes, } \mathrm{n}=48, \mathrm{R}^{2}=0.987, \mathrm{P}<0.001\right)
\end{aligned}
$$

The slope and the intercept of the length-weight regressions for males (slope $\mathrm{F}=9.00, \mathrm{P}=0.004$, d.f. $=1$; intercept $\mathrm{F}=6.43, \mathrm{P}=0.013$, d.f. $=1$ ) and males and females combined (slope $\mathrm{F}=10.27, \mathrm{P}=0.002$, d.f. $=1$; intercept $\mathrm{F}=11.45$, $\mathrm{P}=0.001$, d.f. $=1$ ) were both statistically different between the two lakes (Figs. 3A and 3C), indicating higher, but decreasing differences in weight for length in 1. Mergozzo. In contrast, the length-weight regressions for females had the same slope $(\mathrm{F}=0.91, \mathrm{P}=0.351$, d.f. $=1)$, but different intercepts $(\mathrm{F}=11.45, \mathrm{P}=0.001$, d.f. $=1)$, indicating a constant higher weight-for-length in 1. Mergozzo (Fig. 3B). The exponents (b) for the weight-length regressions in 1. Ghirla were not significantly different from $3(\mathrm{P}>0.05)$ indicating isometric growth in males, females and the sexes pooled. The same result appeared for females in 1. Mergozzo, whilst the $b$ value of the weight-length regressions for males and all sexes pooled in 1. Mergozzo was significantly less than $3(\mathrm{P}=0.005$ and $\mathrm{P}=0.006$, respectively) indicating negative allometric growth.

\begin{tabular}{|c|c|c|c|c|c|c|c|c|c|}
\hline \multirow[b]{2}{*}{$\% \mathrm{~N} \geq 2 \%$} & \multicolumn{3}{|c|}{ L. Ghirla } & \multicolumn{6}{|c|}{ L. Mergozzo } \\
\hline & & $\begin{array}{l}\text { NPUE } \\
( \pm \text { SD })\end{array}$ & $\% \mathrm{~N}$ & $\begin{array}{l}\text { BPUE } \\
( \pm \text { SD })\end{array}$ & $\% \mathrm{~B}$ & $\begin{array}{l}\text { NPUE } \\
( \pm \text { SD })\end{array}$ & $\% \mathrm{~N}$ & $\begin{array}{l}\text { BPUE } \\
( \pm \text { SD })\end{array}$ & $\% \mathrm{~B}$ \\
\hline Gymnocephalus cernuus & Ruffe (nn) & $4.5 \pm 3.1$ & 5.9 & $58.2 \pm 5.3$ & 3.3 & $3.44 \pm 3.2$ & 14.9 & $61.7 \pm 2.6$ & 3.1 \\
\hline Perca fluviatilis & $\operatorname{Perch}(\mathrm{n})$ & $26.9 \pm 4.1$ & 57.0 & $399.4 \pm 6.9$ & 28.9 & $2.14 \pm 2.2$ & 11.8 & $84.94 \pm 3.4$ & 7.9 \\
\hline Rutilus rutilus & Roach (nn) & $20.93 \pm 1.7$ & 28.4 & $1070.3 \pm 2.3$ & 48.1 & $6.5 \pm 3.0$ & 60.1 & $205.7 \pm 6.3$ & 37.3 \\
\hline Scardinius erythrophthalmus & Rudd (n) & $3.6 \pm 3.8$ & 7.8 & $179.0 \pm 4.9$ & 15.0 & $2.6 \pm 2.4$ & 4.8 & $445.7 \pm 4.8$ & 14.4 \\
\hline \multicolumn{10}{|l|}{$\% \mathrm{~N}<2 \%$} \\
\hline Ameiurus melas & Black bullhead (n) & & & & & $1.0 \pm 1.0$ & 0.8 & $28.8 \pm 2.0$ & 0.4 \\
\hline Coregonus lavaretus & European whitefish (nn) & & & & & $1.0 \pm 1.0$ & 0.6 & $85.4 \pm 2.1$ & 0.7 \\
\hline Cottus gobio & Bullhead (nn) & & & & & $1.0 \pm 1.0$ & 0.8 & $2.3 \pm 1.3$ & 0.1 \\
\hline Lepomis gibbosus & Pumpkinseed (nn) & & & & & $1.0 \pm 1.0$ & 0.6 & $23.3 \pm 1.6$ & 0.2 \\
\hline Lota lota & Burbot (n) & & & & & $1.4 \pm 1.6$ & 0.8 & $268.0 \pm 3.7$ & 2.8 \\
\hline Micropterus salmoides & Largemouth bass (nn) & & & & & $1.2 \pm 1.4$ & 1.4 & $63.4 \pm 4.2$ & 1.8 \\
\hline Padogobius martensii & Padanian goby (n) & & & & & $1.0 \pm 1.0$ & 0.8 & $2.3 \pm 1.3$ & 0.1 \\
\hline Rhodeus amarus & Bitterling (nn) & $1.4 \pm 1.6$ & 0.4 & $6.5 \pm 1.1$ & 0.1 & $1.7 \pm 2.2$ & 1.1 & $5.7 \pm 1.6$ & 0.1 \\
\hline Salvelinus alpinus & Arctic charr (n) & & & & & 1 & 0.3 & 97 & 0.4 \\
\hline Sander lucioperca & Pikeperch (nn) & $1.0 \pm 1.0$ & 0.5 & $121.5 \pm 6.8$ & 4.6 & $1.0 \pm 1.0$ & 0.8 & $1038.7 \pm 8.43$ & 27.0 \\
\hline Squalius cephalus & Chub (n) & & & & & $1.4 \pm 1.6$ & 0.8 & $439.4 \pm 1.9$ & 3.7 \\
\hline Total & & $74.6 \pm 1.5$ & & $2714.2 \pm 1.5$ & & $10.1 \pm 2.9$ & & $707.0 \pm 3.4$ & \\
\hline
\end{tabular}

In both lakes the relative weight $\mathrm{Wr}$ was not statistically different between the various length categories for males, females, and males and females pooled (KruskalWallis, $\mathrm{P}>0.05$ ). Significant differences between lakes were detected for males (Mann-Whitney, $U=436.0$, $\mathrm{P}=0.009$ ), females (Mann-Whitney, $\mathrm{U}=34.5, \mathrm{P}=0.034$ ) and males and females pooled (Mann-Whitney, $\mathrm{U}=708.5$, $\mathrm{P}<0.001$ ), indicating higher Wr in 1. Mergozzo (Tab. 2).

Tab. 1. Species composition and geometric means ( \pm geometric standard deviation) of the catch per unit effort [fish number per unit effort (number ind. net ${ }^{-1}$ ) and fish biomass per unit effort $\left.\left(\mathrm{g} \mathrm{net}^{-1}\right)\right]$, abundance $(\%)$ of the total catch (by number and biomass) of fish sampled in lake Ghirla and lake Mergozzo. Species are divided into abundance $\geq 2$ and $<2 \%$.

L. Ghirla, lake Ghirla; L. Mergozzo, lake Mergozzo; NPUE, fish number per unit effort; SD, standard deviation; \%N, abundance (\%) of the total catch by number; BPUE, fish biomass per unit effort; \%B, abundance (\%) of the total catch by biomass; $n n$, non native; $n$, native. 

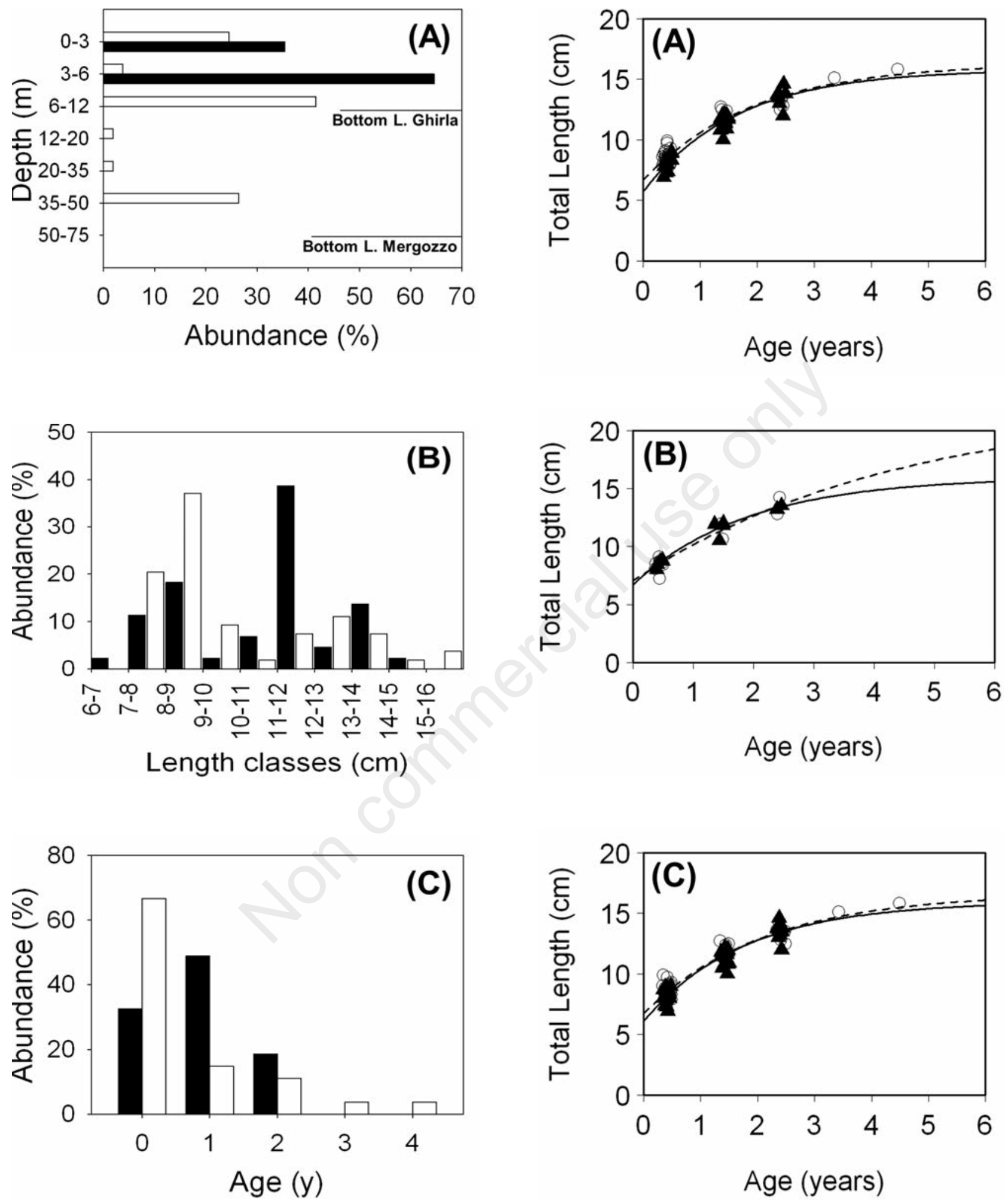

Fig. 1. Fish number per unit effort of ruffe across depth (A), size (B) and age (C) distributions in lake Ghirla (closed bars) and lake Mergozzo (open bars). In (A) the bottom depth of each of the two lakes is indicated by a horizontal line.

Fig. 2. Length-at-age data of ruffe in lake Ghirla (closed triangles) and lake Mergozzo (open circles) for males (A), females (B) and males and females pooled (C). Von Bertalanffy growth function curves are fitted to the data: 1. Mergozzo (short dashed line), 1. Ghirla (unbroken line). 
The VBGF parameters for length are shown in Tab. 2 and length-at-age data are presented in Fig. 3A for males, $3 \mathrm{~B}$ for females, and $3 \mathrm{C}$ for males and females pooled, respectively. The comparison of the VBGF parameters (Tab. 3) showed that the best model for males and pooled sexes was the one with $\mathrm{L}_{\infty}$ and $\mathrm{K}$ in common, whilst the model with all three parameters in common (common model) was most parsimonious for the females. Thus, the $t_{0}$ parameter was significantly higher for males, and males and females combined in 1. Mergozzo than in 1. Ghirla. For the other parameters no significant differences were detected.

The proportion of females in the sample was 0.31 in 1. Ghirla and 0.29 in 1 . Mergozzo, a non-significant difference $\left(\mathrm{Chi}^{2}=0.568, \mathrm{P}=0.812\right.$, d.f. $\left.=1\right)$. All the individuals were sexually mature. The gonad weight, adjusted for body size, was significantly different between lakes for both males (slope $\mathrm{F}=7.16, \mathrm{P}=0.009$, d.f. $=1$; intercept
$\mathrm{F}=3.37, \mathrm{P}=0.070$, d.f. $=1$ ) and females (slope $\mathrm{F}=6.63$, $\mathrm{P}=0.018$, d.f. $=1$; intercept $\mathrm{F}=9.66, \mathrm{P}=0.005$, d.f. $=1$ ), indicating higher (but decreasing with increasing body size) differences in gonad weight for body size in 1. Mergozzo.

\section{Diet and intraspecific food niche overlap}

In both lakes, the stomach contents of ruffe comprised both benthic and pelagic organisms but were dominated by benthic invertebrates (Fig. 4). Chironomid larvae were the most abundant food items in 1. Mergozzo (Fig. 4A), whilst in lake Ghirla organisms of the Nemertea order also occurred in high abundances, although less frequently than chironomid larvae (Fig. 4B). The ratio between benthic and pelagic organisms (based on number) in the diet increased significantly with increasing fish size in both lakes (exponential fit, $\mathrm{P}<0.05, \mathrm{R}^{2}=0.397$ for 1 . Mergozzo

Tab. 2. Von Bertalanffy growth function parameters for total length, relative weight (medians) and Phi' values of ruffe in lake Ghirla and lake Mergozzo.

\begin{tabular}{|c|c|c|c|c|c|c|}
\hline & \multicolumn{3}{|c|}{ L. Ghirla } & \multicolumn{3}{|c|}{ L. Mergozzo } \\
\hline & Males & Females & Pooled & Males & Females & Pooled \\
\hline $\begin{array}{l}\mathrm{L}_{\infty}(\mathrm{cm}) \\
\text { (C.I. } 95 \%)\end{array}$ & $\begin{array}{c}15.82 \\
(13.87-21.27)\end{array}$ & $\begin{array}{c}15.98 \\
(13.13-29.72)\end{array}$ & $\begin{array}{c}15.96 \\
(14.12-20.78)\end{array}$ & $\begin{array}{c}16.72 \\
(14.96-19.54)\end{array}$ & $\begin{array}{c}22.26 \\
(13.35-49.66)\end{array}$ & $\begin{array}{c}17.07 \\
(15.10-19.76)\end{array}$ \\
\hline $\begin{array}{l}\mathrm{K}\left(\mathrm{y}^{-1}\right) \\
\left(\text { C.I. }{ }_{95 \%}\right)\end{array}$ & $\begin{array}{c}0.6057 \\
(0.2797-0.9905)\end{array}$ & $\begin{array}{c}0.5208 \\
(0.1333-1.1835)\end{array}$ & $\begin{array}{c}0.5668 \\
(0.2988-0.9227)\end{array}$ & $\begin{array}{c}0.5165 \\
(0.3071-0.7724)\end{array}$ & $\begin{array}{c}0.2285 \\
(0.0679-1.1360)\end{array}$ & $\begin{array}{c}0.4661 \\
(0.2959-0.6969)\end{array}$ \\
\hline $\begin{array}{l}\text { t0 (y) } \\
\text { (C.I. } 95 \%)\end{array}$ & $\begin{array}{c}-2.0862 \\
(-1.3240--0.4066)\end{array}$ & $\begin{array}{c}-2.4087 \\
(-2.1092--0.4283)\end{array}$ & $\begin{array}{c}-2.1927 \\
(-1.4120--0.5024)\end{array}$ & $\begin{array}{c}-1.6698 \\
(-1.4952--0.6528)\end{array}$ & $\begin{array}{c}-2.4087 \\
(-2.1091--0.4283)\end{array}$ & $\begin{array}{c}-1.6531 \\
(-1.5656-0.7458)\end{array}$ \\
\hline $\begin{array}{l}\mathrm{Wr} \\
\text { (C.I. } 95 \%)\end{array}$ & $\begin{array}{c}126.3 \\
(120.9-127.4)\end{array}$ & $\begin{array}{c}123.3 \\
(117.3-130.7)\end{array}$ & $\begin{array}{c}125.6 \\
(121.3-126.9)\end{array}$ & $\begin{array}{c}131.1 \\
(128.1-137.7)\end{array}$ & $\begin{array}{c}138.4 \\
(128.4-139.7)\end{array}$ & $\begin{array}{c}132.1 \\
(129.3-137.0)\end{array}$ \\
\hline $\begin{array}{l}\text { Phi' prime } \\
\text { (C.I. }{ }_{95 \%} \text { ) }\end{array}$ & $\begin{array}{c}2.18 \\
(1.73-2.65)\end{array}$ & $\begin{array}{c}2.12 \\
(1.36-3.02)\end{array}$ & $\begin{array}{c}2.16 \\
(1.78-2.60)\end{array}$ & $\begin{array}{c}2.16 \\
(1.84-2.47)\end{array}$ & $\begin{array}{c}2.05 \\
(1.08-3.45)\end{array}$ & $\begin{array}{c}2.13 \\
(1.83-2.43)\end{array}$ \\
\hline
\end{tabular}

L. Ghirla, lake Ghirla; L. Mergozzo, lake Mergozzo; $L_{\infty}$, theoretical asymptotic length that an average fish may achieve; C.I., confidence interval; $K$, constant [year $\left.\left(y^{-1}\right)\right]$ determining how fast the fish approaches $L_{\infty} ; t_{0}$, hypothetical age at $L_{T}=0 ; \mathrm{Wr}$, relative weight.

Tab. 3. Results of the comparison of Von Bertalanffy growth function models for the different groups (males, females and sexes pooled) between the two lakes. Models include a general model which holds separate Von Bertalanffy growth function parameter estimates in each group, and different common models with one $\left(1 \mathrm{Kt} 0,1 \mathrm{~L}_{\infty} \mathrm{t} 0,1 \mathrm{~L}_{\infty} \mathrm{K}\right)$, two $\left(2 \mathrm{~T}, 2 \mathrm{~K}, 2 \mathrm{~L}_{\infty}\right)$ or three $($ Com) parameters in common among groups.

\begin{tabular}{lcccccccc}
\hline & Males & \multicolumn{3}{c}{ Females } & \multicolumn{2}{c}{ Pooled sexes } \\
\hline Model & d.f. & AIC & Model & d.f. & AIC & Model & d.f. & AIC \\
\hline Gen & 7 & 182.69 & Gen & 7 & 49.40 & Gen & 7 & 142.27 \\
$1 \mathrm{Kt} 0$ & 6 & 180.83 & $1 \mathrm{Kt0}$ & 6 & 47.82 & $1 \mathrm{Kt0}$ & 6 & 140.36 \\
$1 \mathrm{~L}_{\infty} \mathrm{t} 0$ & 6 & 180.89 & $1 \mathrm{~L}_{\infty} \mathrm{t} 0$ & 6 & 47.81 & $1 \mathrm{~L}_{\infty} \mathrm{t} 0$ & 6 & 140.43 \\
$1 \mathrm{~L}_{\infty} \mathrm{K}$ & 6 & 181.23 & $1 \mathrm{~L}_{\infty} \mathrm{K}$ & 6 & 47.74 & $\mathrm{~L}_{\infty} \mathrm{K}$ & 6 & 140.97 \\
$2 \mathrm{t} 0^{\circ}$ & 5 & 178.99 & $2 \mathrm{t} 0$ & 5 & 45.82 & $2 \mathrm{t} 0^{\circ}$ & 5 & 138.59 \\
$2 \mathrm{~K}$ & 5 & 179.72 & $2 \mathrm{~K}$ & 5 & 45.83 & $2 \mathrm{~K}$ & 5 & 139.94 \\
$2 \mathrm{~L}_{\infty}$ & 5 & 180.46 & $2 \mathrm{~L}_{\infty}$ & 5 & 45.89 & $2 \mathrm{~L}_{\infty}$ & 5 & 141.57 \\
Com & 4 & 180.41 & Com $^{\circ}$ & 4 & 44.07 & Com $^{\circ}$ & 4 & 143.02 \\
\hline
\end{tabular}

d.f., degree of freedom; AIC, Akaike information criterion; Gen, general model. ${ }^{\circ}$ The most parsimonious models, i.e. those with the lowest Akaike information criterion. 

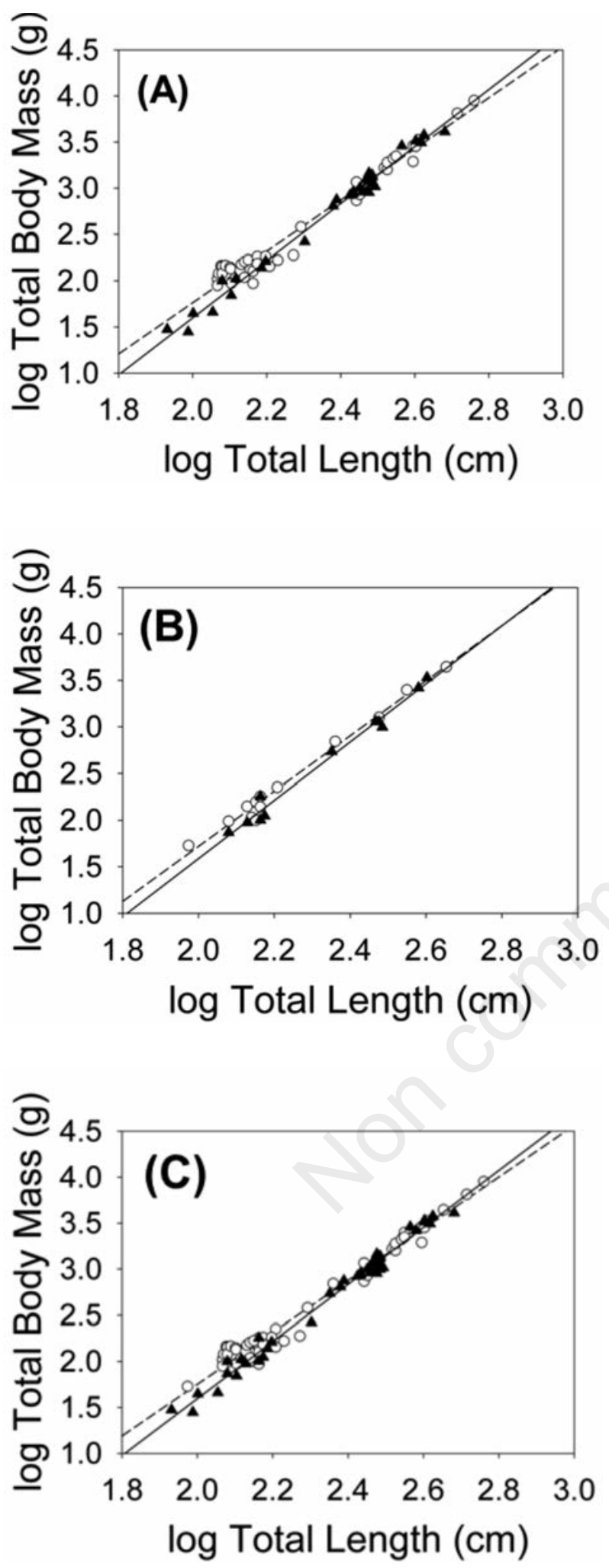

Fig. 3. Length-weight data of ruffe in lake Ghirla (closed triangles) and lake Mergozzo (open circles) for males (A), females (B) and males and females pooled (C). Ordinary least squares regressions are fitted on the data: 1. Mergozzo (short dashed line), 1. Ghirla (unbroken line). and $\mathrm{R}^{2}=0.253$ for 1 . Ghirla). The food niche overlap was generally relatively low in both 1 . Mergozzo $(\alpha=0.623)$ and 1. Ghirla $(\alpha=0.558)$. Among age classes, the food niche overlap was highest between $0^{+}$and $1^{+}$individuals in both 1. Mergozzo $(\alpha=0.758)$ and 1. Ghirla $(\alpha=0.678)$, but then decreased between $1^{+}$and $2^{+}(\alpha=0.629$ and $\alpha=0.498$, respectively $)$ and $0^{+}$and $2^{+}(\alpha=0.492$ and $\alpha=0.498$, respectively).

\section{DISCUSSION}

Alien invasive species are often characterised by high physiological tolerance and functional characteristics enabling them to occupy vacant niches in the life history space and to spread rapidly (Moyle and Marchetti, 2006; Bollache et al., 2008). This study shows that ruffe is not an exception. Indeed, although this species has been reported to typically colonise meso-eutrophic environments in Northern Europe (Persson et al., 1991; Jeppesen et al., 2000; Mehner et al., 2005), the results of the present study reveal that ruffe is capable of establishing viable and large populations irrespective of the trophic level of the invaded lake.

Our results indicate a better body condition for ruffe in the oligotrophic and more recently invaded 1. Mergozzo as the body growth and relative weight here were higher than in eutrophic 1. Ghirla. Furthermore, gonad weight (adjusted for body size) was higher in 1. Mergozzo than in 1. Ghirla. This concurs with Devine et al.'s findings (2000) and shows that expanding ruffe populations have a stronger reproductive potential than well-established ones, although we cannot rule out factors unrelated to invasion chronology and more related to the difference in depth (Emmrich et al., 2011) or water level fluctuations (Sutela et al., 2011). Overall, our findings indicate that the ruffe population in 1. Mergozzo apparently is still undergoing a boom-and-bust development, as often detected in the early phases of fish invasions (Salonen et al., 2007; Volta and Jepsen, 2008; Liso et al., 2011), while the population in 1. Ghirla, established more than 15 years ago, is more balanced and stable. Similar patterns in ruffe population dynamics have been recorded in other lakes, for instance in a new reservoir in Russia (Popova et al., 1998), in Loch Lomond (UK) (Devine et al., 2000) and Llyn Tegid (UK) (Winfield et al., 2011).

The calculated body growth parameters of ruffe in 1 . Mergozzo and in 1. Ghirla including asymptotic length (Tab. 4) were within the range of those previously reported in the literature. However, the number of age classes found was lower than that of other European lakes (Tab. 3 in Ogle, 1998). Also, the Phi' values are among the highest recorded, indicating a fast growth rate characteristic of fish living in eutrophic environments and/or warm waters at southern latitudes (Blanck and Lammoroux, 2007; Jeppesen et al., 2010, 2012). Additionally, in both lakes we found ruffes to have well developed gonads, indicating that 
all fish were likely to reproduce during the next spawning season, at age 1+. Our results, therefore, provide further evidence that fish at southern latitudes tend to grow faster and reproduce earlier (Blanck and Lammoroux, 2007; Jeppesen et al., 2010, 2012).

The food niche overlap between age classes was low in both lakes and benthic organisms, especially chironomids, were the main food items for ruffe, together with smaller amounts of zooplankton. The importance of chironomids in the diet is well-known for both northern
(Kålås, 1995; Kangur et al., 1999) and southern European lakes (Lorenzoni et al., 2007). Zooplankton consumption, in contrast, is limited to summer periods and young individuals (Bergman, 1991; Kålås, 1995). Indeed, we found a significant increase of benthos in the diet with increasing fish size, which is in agreement with many earlier studies (Hölker and Thiel, 1998; Kangur et al., 2003; Reszu and Specziar, 2006; Tarvainen et al., 2008) classifying ruffe as an invertivore (Balon et al., 1977). However, it must be noted that our study covered a limited time period in
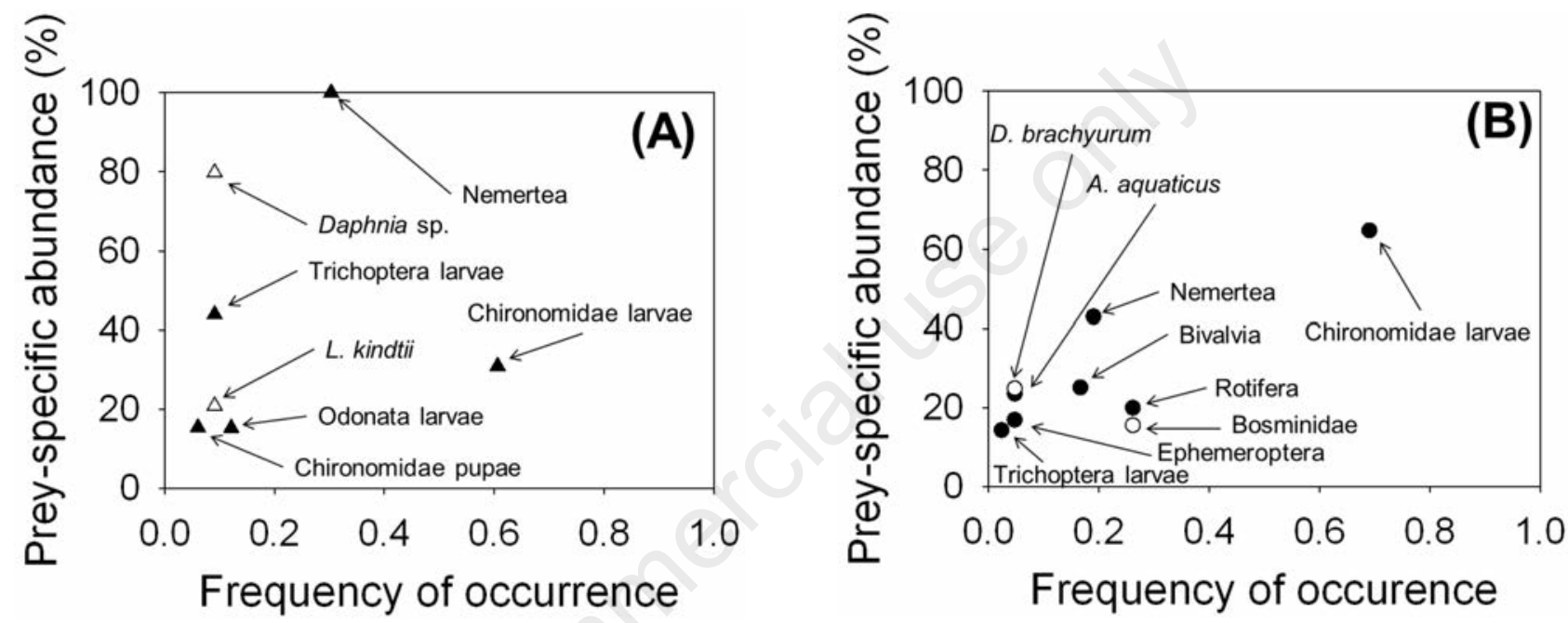

Fig. 4. Stomach contents (limited to prey with a frequency of occurrence $>0.1$ ) of ruffe in lake Ghirla (A) and lake Mergozzo (B) following the method of Amundsen et al. (1996). Benthic organisms are indicated by closed symbols, pelagic organisms by open symbols.

Tab. 4. Life history parameters, including Von Bertalanffy growth function parameters, of the ruffe populations of lake Ghirla and lake Mergozzo compared with populations in other European waters.

\begin{tabular}{|c|c|c|c|c|c|}
\hline Author & Lake and country & $\mathrm{L}_{\infty}(\mathrm{cm})$ & $\mathrm{K}\left(\mathrm{y}^{-1}\right)$ & t0 (y) & $\begin{array}{c}\text { Overall growth } \\
\text { performance }\left(\Phi^{\prime}\right)^{\circ}\end{array}$ \\
\hline Neuhaus (1934) & Zalew Wislany (former U.S.S.R.) & 18.99 & 0.42 & -0.31 & 2.18 \\
\hline Birò (1971) & Lake Balaton (Hungary) & 13.00 & 0.29 & -0.522 & 1.68 \\
\hline Bauch (1954) & 25 lakes (Germany) & 13.75 & 0.50 & -0.13 & 1.98 \\
\hline Willemsen (1977) & Ijsselmeer (Netherlands) & 16.50 & 0.20 & -1.42 & 1.74 \\
\hline Willemsen (1977) & Lauwersmeer (Netherlands) & 19.80 & 0.90 & 0.43 & 2.54 \\
\hline Winfield et al. (1996) & Loch Lomond (UK) & 13.70 & 0.33 & -0.78 & 1.80 \\
\hline Winfield et al. (1996) & Llyn Tegid (UK) & 25.2 & 0.07 & -3.41 & 1.69 \\
\hline Neja (1989) & Szecin lagoon (Poland) & 14.63 & 0.37 & -0.23 & 1.90 \\
\hline Neja (1989) & Odra Mouth (Poland) & 17.10 & 0.21 & -0.97 & 1.79 \\
\hline Neja (1989) & Lake Dabie (Poland) & 16.39 & 0.23 & -0.86 & 1.79 \\
\hline Jamet and Desmolles (1994) & Lake Aydat (France) & 15.20 & 0.49 & -0.31 & 2.05 \\
\hline Lorenzoni et al. (2009) Females & Piediluco (Italy) & 21.82 & 0.27 & -0.61 & 2.10 \\
\hline Lorenzoni et al. (2009) Males & Piediluco (Italy) & 16.15 & 0.32 & -0.70 & 1.92 \\
\hline Present study & Lake Ghirla (Italy) & 15.96 & 0.57 & -1.65 & 2.16 \\
\hline Present study & Lake Mergozzo (Italy) & 17.07 & 0.47 & -2.19 & 2.13 \\
\hline
\end{tabular}

$L_{\infty}$, theoretical asymptotic length which an average fish may achieve; $K$, constant [year $\left(y^{-1}\right)$ ] determining how fast the fish approaches $L_{\infty} ; t_{0}$, hypothetical age at $L_{T}=0 .{ }^{\circ}$ Calculated following Pauly and Munro (1984). 
October, potentially preventing us from detecting other feeding patterns such as predation on fish eggs, larvae or juveniles as found in some other lakes (Kangur and Kangur, 1996; Rösch and Schmid, 1996; Winfield et al., 1996, 2004b; Etheridge et al., 2011).

\section{CONCLUSIONS}

In conclusion, the results from our study lakes revealed that ruffe has been capable of establishing viable and large populations irrespective of the trophic level of the invaded lake and that the population densities have subsequently remained relatively high. The observed differences in life history traits of the two populations probably reflect differences in the timing of colonisation and appear to override the effect of lake trophic status. The data collected in this study provide a valuable starting point to explore the ecology of ruffe in the lakes of Northern Italy.

\section{AKNOWLEDGMENTS}

The authors thank Mr. Igorio Cerutti for the invaluable assistance with field sampling and laboratory work. We also thank the Fishery Office of the Varese Province for sampling permissions for 1 . Ghirla and the Mergozzo Municipality for permissions for 1. Mergozzo. Pietro Volta, Erik Jeppesen, Matthias Emmrich and Ian J. Winfield were funded by the EU FP-7 WISER project. Barbara Campi was funded by a grant of the Fondazione Comunitaria del VCO. Paolo Sala and Pietro Volta were funded by the LIFE+ INHABIT project. Erik Jeppesen was also supported by the EU FP-7 Theme 6 project REFRESH (Adaptive strategies to Mitigate the Impacts of Climate Change on European Freshwater Ecosystems, Contract No.: 244121), CLEAR (a Villum Kann Rasmussen Centre of Excellence project), CRES, CIRCE and ARC. Finally, the authors are thankful to two anonymous referees who contributed to improve the manuscript significantly.

\section{REFERENCES}

Adams CE, Tippett R, 1991. Powan, Coregonus lavaretus (L.), ova predation by newly introduced ruffe, Gymnocephalus cernuus (L.), in Loch Lomond, Scotland. Aquac. Res. 22:239-246.

Amundsen PA, Gabler HM, Staldvik FJ, 1996. A new approach to graphical analysis of feeding strategy from stomach contents data-modification of the Costello (1990) method. J. Fish Biol. 48:607-614.

Appelberg M, Berger HM, Hesthagen T, Kleiven E, Kurkilahti M, Raitaniemi J, Rask M, 1995. Development and intercalibration of methods in Nordic freshwater fish monitoring. Water Air Soil Poll. 85:401-406.

Balon EK, Momot WT, Regier HA, 1977. Reproductive guilds of percids: results of the paleogeographical history and ecological succession. J. Fish. Res. Board Can. 34:1910-1921.

Baty F, Delignette-Muller ML, 2012. Nlstools: tools for nonlin- ear regression diagnostics. Available fom: http://cran.r-project.org/web/packages/nlstools/

Bauch G, 1954. [Die einheimischen Süsswasserfische]. [Book in German]. Neuman Verlag, Radebeul and Berlin: 199 pp.

Berg LS, 1965. Freshwater fishes of the U.S.S.R. and adjacent countries. Israel Program for Scientific Translations Publ., Jerusalem: $1381 \mathrm{pp}$.

Bergman E, 1987. Temperature-dependent differences in foraging ability of two percids, Perca fluviatilis and Gymnocephalus cernuus. Environ. Biol. Fish. 19:45-53.

Bergman E, 1991. Changes in abundance of two percids, Perca fluviatilis and Gymnocephalus cernuus, along a productivity gradient: Relations to feeding strategies and competitive abilities. Can. J. Fish. Aquat. Sci. 48:536-545.

Bergman E, Greenberg LA, 1994 Competition between a planktivore, a benthivore, and a species with ontogenetic diet shifts. Ecology 75:1233-1245.

Birò P, 1971. Growth investigation of ruffe (Acerina cernua L.) in Lake Balaton. Ann. Inst. Biol. Hung. Acad. Sci. 38:131-142.

Blanck A, Lammouroux N, 2007. Large-scale intraspecific variation in life-history traits of European freshwater fish. J. Biogeogr. 34:862-875.

Bollache L, Dick JTA, Farnsworth KD, Montgomery WI, 2008. Comparison of the functional responses of invasive and native amphipods. Biol. Letters 4:166-169.

Campaioli S, Ghetti PF, Minelli A, Ruffo S, 1994. [Manuale per il riconoscimento dei macroinvertebrati delle acque dolci italiane]. [Book in Italian]. Trento Province ed., Trento: 357 pp.

Carosi A, Dorr M, Giovinazzo G, Lorenzoni L, Mearelli M, 1998. [Gymnocephalus cernuus (Linnaeus, 1758) (Osteichthyes, Percidae) nel bacino del fiume Tevere]. [Article in Italian]. Quad. ETP 27:103-108.

Chiara G, 1986. [Prima segnalazione di Acerina (Gymnocephalus cernua L. (Osteichthyes Perciformes) per l'Italia]. [Article in Italian]. Quad. ETP 13:59-60.

Chiozzi G, 1995. [Prima segnalazione di Blicca bjoerkna (Osteichthyes, Cyprinidae) per l'Italia e presenza di Acerina cernua (Osteichthyes, Percidae) in una lanca del basso corso dell'Adda (Provincia di Lodi)]. [Article in Italian]. Atti Soc. it. Sci. nat. Museo civ. Stor. nat. Milano 134:313-315.

Czypinski GD, Ogle DH, 2011. Evaluating the physical removal of ruffe (Gymnocephalus cernuus) with bottom trawling. J. Freshwater Ecol. 26:441-443.

Dawson VK, Bills TD, Boogard MA, 1998. Avoidance behavior of ruffe exposed to selected formulations of piscicides. J. Great Lakes Res. 24:343-350.

De Curtis O, Rossi R, 1999. [Prima segnalazione di Acerina Gymnocephalus cernuus (Linneo, 1758) (Osteichthyes, Perciformes) nelle acque interne della Provincia di Ferrara]. [Article in Italian]. Ann. Mus. civ. St. nat. Ferrara 2:89-90.

Devine JA, Adams CE, Maitland PS, 2000. Changes in reproductive strategy in the ruffe during a period of establishment in a new habitat. J. Fish Biol. 56:1488-1496.

Emmrich M, Brucet S, Ritterbush D, Mehner T, 2011. Size spectra of lake fish assemblages: responses along gradient of general environmental factors and intensity of lake-use. Freshwater Biol. 56:2316-2333.

Etheridge EC, Bean CW, Adams CE, 2011. An experimental approach to estimating vulnerability of European whitefish (Coregonus lavaretus) ova to predation by invasive ruffe 
(Gymnocephalus cernuus). Ecol. Freshw. Fish 20:299-307. Giussani G, 1994. [Prime indagini sulla fauna ittica del Lago di Mergozzo]. [Book in Italian]. CNR Publ., Roma: 12 pp.

GRAIA, 2000. [Carta ittica della provincia del Verbano Cusio Ossola. Provincia del V.C.O. Settore tutela faunistica]. [Book in Italian]. Gestione e Ricerca Ambientale Ittica Acque Publ., Varano Borghi: 140 pp.

GRAIA, 2001. [Carta Ittica della Provincia di Varese. Provincia del V.C.O. Settore Caccia Pesca e Agricoltura]. [Book in Italian]. Gestione e Ricerca Ambientale Ittica Acque Publ.

Gunderson JL, Klepinger MR, Bronte CR, Marsden JE, 1998. Overview of the international symposium on Eurasian ruffe (Gymnocephalus cernuus): biology, impacts, and control. J. Great Lakes Res. 24:165-169.

Hokanson KEF, 1977. Temperature requirements of some percids and adaptations to the seasonal temperature Cycle. J. Fish. Res. Board Can. 13:175-180.

Hölker F, Thiel R, 1998. Biology of ruffe (Gymnocephalus cernuus (L.)). A review of selected aspects from European literature. J. Great Lakes Res. 24:186-204.

Jamet JL, Desmolles F, 1994. Growth, reproduction and condition of roach (Rutilus rutilus (L.)), perch (Perca fluviatilis, L.) and ruffe (Gymnocephalus cernuus (L.)) in eutrophic Lake Aydat (France). Int. Rev. Ges. Hydrobio. 79:305-322.

Jeppesen E, Jensen JP, Søndergaard M, Lauridsen T, Landkildehus F, 2000. Trophic structure, species richness and biodiversity in Danish lakes: changes along a phosphorus gradient. Freshwater Biol. 45:201-213.

Jeppesen E, Meerhoff M, Holmgren K, González-Bergonzoni I, Teixeira-de Mello F, Declerck SAJ, DeMeester L, Søndergaard M, Lauridsen TL, Bjerring R, Conde-Porcuna JM, Mazzeo N, Iglesias C, Reizenstein M, Malmquist HJ, Liu Z, Balayla D, Lazzaro X, 2010. Impacts of climate warming on lake fish community structure and potential effects on ecosystem function. Hydrobiologia 646:73-90.

Jeppesen E, Mehner T, Winfield IJ, Kangur K, Sarvala J, Gerdeaux D, Rask M, Malmquist HJ, Holmgren K, Volta P, Romo S, Eckmann R, Sandström A, Blanco S, Kangur A, Stabo HR, Tarvainen M, Ventelä AM, Søndergaard M, Lauridsen TL, Meerhoff M, 2012. Impacts of climate warming on the long-term dynamics of key fish species in 24 European lakes. Hydrobiologia 694:1-39.

Kålås S, 1995. The ecology of ruffe Gymnocephalus cernuus (Pisces: Percidae) introduced to Mildevatn, western Norway. Environ. Biol. Fish. 42:219-232.

Kangur K, Kangur A, 1996. The composition and seasonal changes in the diet of ruffe (Gymnocephalus cernuus) in Lake Vortsjarv, Estonia. P. Est. Acad. Sci. 45:1-14.

Kangur K, Kangur A, Kangur P, 1999. A comparative study on the feeding of eel, Anguilla anguilla (L.), bream, Abramis brama (L.) and ruffe, Gymnocephalus cernuus (L.) in Lake Võrtsjärv, Estonia. Hydrobiologia 408/409:65-72.

Kangur P, Kangur A, Kangur K, Möls T, 2003. Condition and growth of ruffe Gymnocephalus cernuus (L.) in two large shallow lakes with different fish fauna and food resource. Hydrobiologia 506/509:435-441.

Kottelat M, Freyhof J, 2007. Handbook of European freshwater fishes. Kottelat Publ., Kornol: 646 pp.

Lind EA, 1977. A review of pikeperch Stizosteidon lucioperca, Eurasian perch Perca fluviatilis and ruffe, Gymnocephalus cernua, in Finland. J. Fish. Res. Board Can. 34:1684-1695.

Liso S, Gjelland KØ, Reshetnikov YS, Amundsen PA, 2011. A planktivorous specialist turns rapacious: piscivory in invading vendace Coregonus albula. J. Fish Biol. 78:332-337.

Lorenzoni M, Carosi A, Pedicillo G, Trusso A, 2007. A comparative study on the feeding competition of the European perch Perca fluviatilis L. and the ruffe Gymnocephalus cernuus (L.) in Lake Piediluco (Umbria, Italy). B. Fr. Peche Piscic. 387:35-57.

Lorenzoni M, Pace R, Pedicillo G, Viali P, Carosi A, 2009. Growth, catches and reproductive biology of ruffe Gymnocephalus cernuus in Lake Piediluco (Umbria, Italy). Folia Zool. 58:420-435.

Maitland PS, East K, 1989. An increase in numbers of ruffe, Gymnocephalus cernua, in a Scottish loch from 1982 to 1987. Aquacult. Fish. Manag. 20:227-228.

Margaritora F, 1983. Cladoceri (Crustacea: Cladocera). [Guide per il riconoscimento delle specie animali delle acque interne italiane, 22]. [Book in Italian]. CNR Publ., Roma: 168 pp.

Matthey G, 1966. Two species new to the fauna of the lake Geneva: Dreissena polymorpha Pallas (Mollusca, Dreissenidae), Acerina Cernua (L) (Pisces, Percidae). Bull. Soc. Vaudoise Sci. Nat. 69:229-232.

Mayo KR, Selgeby JH, McDonald ME, 1998. A bioenergetic modelling evaluation of top-down control of ruffe in the St. Luise River, western Lake Superior. J. Great Lakes Res. 24:329-342.

Mehner T, Diekmann M, Brämick U, Lemcke R, 2005. Composition of fish communities in German lakes as related to lake morphology, trophic state, shore structure and human use intensity. Freshwater Biol. 50:70-85.

Moyle PB, Marchetti MP, 2006. Predicting invasion success: freshwater fishes in California as a model. Bioscience 56:515-524.

Neja Z, 1989. The growth rate of ruffe, Gymnocephalus cernuus (L. 1758) in the Szczecin lagoon, the Odra Mouth and Lake Dabie. Acta Ichthyol. Piscat. 19:3-19.

Neuhaus E, 1934. [Studien über das Stettiner Haff und seine Nebengewasser. II Unterschungen über den Kaulbarsch]. [Article in German]. Zeitschr. Fisch. 32:1-35.

Ogle DH, 1998. A synopsis of the biology and life history of Ruffe. J. Great Lakes Res. 24:170-185.

Ogle DH, 2012. FishR using R for fisheries analyses. Available from: http://www.ncfaculty.net/dogle/fishR/ Accessed: $12 / 11 / 2012$.

Ogle DH, Winfield IJ, 2009. Ruffe length-weight relationships with a proposed standard weight equation. North Am. J. Fish Manage. 29:850-858.

Pauly D, Munro JL, 1984. Once more on the comparison of growth in fish and invertebrates. Fishbyte 2:21-22.

Persson L, Diehl S, Johansson L, Andersson G, Hamrin SF, 1991. Shifts in fish communities along the productivity gradient of temperate lakes-patterns and the importance of sizestructured interactions. J. Fish. Biol. 38:281-293.

Pihu E, Maemets A, 1982. The management of fisheries in Lake Vortsjarv. Hydrobiologia 86:207-210.

Popova OA, Reshetnikov YS, Kiyashko VI, Dgebuadze YY, Mikheev VN, 1998. Ruffe from the former USSR: variability within the largest part of its natural range. J. Great Lakes Res. 24:263-284. 
Pratt DM, Blust WH, Selgeby JH, 1992. Ruffe, Gymnocephalus cernuus L.: newly introduced in North America. Can. J. Fish. Aquat. Sci. 49:1616-1618.

R Development Core Team, 2010. R: A language and environment for statistical computing. R Foundation for Statistical Computing, Vienna. Available from: http://www.R-project.org

Reszu E, Specziar A, 2006. Ontogenetic diet profiles and sizedependent diet partitioning of ruffe Gymnocephalus cernuus, perch Perca fluviatilis and pumpkinseed Lepomis gibbosus in Lake Balaton. Ecol. Freshw. Fish 15:339-349.

Rösch R, Schmid W, 1996. Ruffe (Gymnocephalus cernuus L.,) newly introduced into Lake Constance: preliminary data on population biology and possible effects on whitefish (Coregonus lavaretus L.). Ann. Zool. Fenn. 33:467-471.

Salonen E, Amundsen PA, Bøhn T, 2007. Invasion, boom and bust by vendace (Coregonus albula) in the subarctic Lake Inari, Finland and the Pasvik watercourse, Norway. Adv. Limnol. 60:331-342.

Sandlund OT, Naesje TF, Klyve L, Lindem T, 1985. The vertical distribution of fish species in Lake Miolsa, Norway, as shown by gill-net catches and echo sounder. Rep. Inst. Freshw. Res. Drottningholm 62:136-149.

Savino JF, Kolar CS, 1996. Competition between nonindigenous ruffe and native yellow perch (Perca flavescens) in laboratory studies. T. Am. Fish. Soc. 125:562-571.

Schoener TW, 1970. Nonsynchronous spatial overlap of lizards in patchy habitats. Ecology 51:408-418.

Sutela T, Vehanen T, Rask M, 2011. Assessment of the ecological status of regulated lakes: stressor-specific metrics from littoral fish assemblages. Hydrobiologia 675:55-64.

Tarvainen M, Vurio K, Sarvala J, 2008. The diet of ruffe Gym- nocephalus cernuus (L.) in northern lakes: new insights from stable isotope analyses. J. Fish Biol. 72:1720-1735.

Volta P, Jepsen N, 2008. The recent invasion of roach (Pisces: Cyprinidae) in a large South-Alpine Lake. J. Limnol. 67:163-170.

Von Bertalanffy L, 1938. A quantitative theory of organic growth. Hum. Biol. 10:181-213.

Willemsen J, 1977. Population dynamics of percids in Lake Ijssel and some smaller lakes in the Netherlands. J. Fish. Res. Board Can. 34:1710-1719.

Winfield IJ, Adams CE, Fletcher JM, 1996. Recent introductions of the ruffe (Gymnocephalus cernuus) to three United Kingdom lakes containing Coregonus species. Ann. Zool. Fenn. 33:459-466.

Winfield IJ, Durie NC, 2004. Fish introductions and their management in the English Lake District. Fisheries Manag. Ecol. $11: 1-7$

Winfield IJ, Fletcher JM, James JB, 2004a. Coexistence of the Eurasian perch (Perca fluviatilis) and an introduced population of ruffe (Gymnocephalus cernuus): an 11 year study, p. 97-98. In: T.P. Barry, J.A. Malison (eds.), Proc. Percis III: Third Int. Percid Fish Symp. University of Wisconsin Sea Grant Institute, Madison, WI, USA.

Winfield IJ, Fletcher JM, James JB, 2004b. Conservation ecology of the vendace (Coregonus albula) in Bassenthwaite Lake and Derwent Water, U.K. Ann. Zool. Fenn. 41:155-164.

Winfield IJ, Fletcher JM, James JB, 2011. Invasive fish species in the largest lakes of Scotland, Northern Ireland, Wales and England: the collective U.K. experience. Hydrobiologia 660:93-103. 